\title{
CORRIGENDUM
}

\section{Molecular Cloning of Multiple Xylanase Genes from Pseudomonas fluorescens subsp. cellulosa}

\author{
By HARRY J. GILBERT, DEBRA A. SULlivan, GAIL JENKINS, \\ LOUISE E. KELLETT, NIGEL P. MINTON AND JUDITH HALL
}

Journal of General Microbiology (1988), 134, 3239-3247

In this paper the authors state that plasmids pGHJ4 and pGHJ5 probably encode distinct but homologous xylanase genes. This was based on different restriction maps in the region of the two genes. However, the authors now realize that an error has been made and in fact pGHJ4 contains a BamHI site at position 7.3 and the Pst I site shown in Fig. 1 at $9 \cdot 2$ is just to the left of Bam HI at $8 \cdot 8$. In addition the EcoRI site $(9 \cdot 8)$ is $0.3 \mathrm{~kb}$ to the right of the SmaI site at position $10 \cdot 0$. Thus, one is forced to conclude that the xylanase genes encoded by pGHJ 4 and pGHJ 5 are the same gene. This possibility was acknowledged in the Discussion of the paper. These data, however, do not alter the fact that there is a homologous sequence in the pseudomonad genome which hybridizes with the xylanase gene encoded by pGHJ5 and pGHJ4. 